\title{
Educational Model of PAKEM in Compliance with Fe Tablet Consumption of Adolescent Girls
}

\author{
Rusmayanty Rusdin ${ }^{1 *}$, Andi Zulkifli Abdullah ${ }^{1}$ (D), Wahiduddin Wahiduddin ${ }^{1}$, Ansariadi Ansariadi ${ }^{1}$ (D), Suriah Suriah ${ }^{2}$ (ID, \\ Healthy Hidayanty ${ }^{3}$ (D) \\ ${ }^{1}$ Department of Epidemiology, Faculty of Public Health, Hasanuddin University, Makassar, Indonesia; ${ }^{2}$ Department of Health \\ Promotion, Faculty of Public Health, Hasanuddin University, Makassar, Indonesia; ${ }^{3}$ Department of Nutrition, Faculty of Public \\ Health, Hasanuddin University, Makassar, Indonesia
}

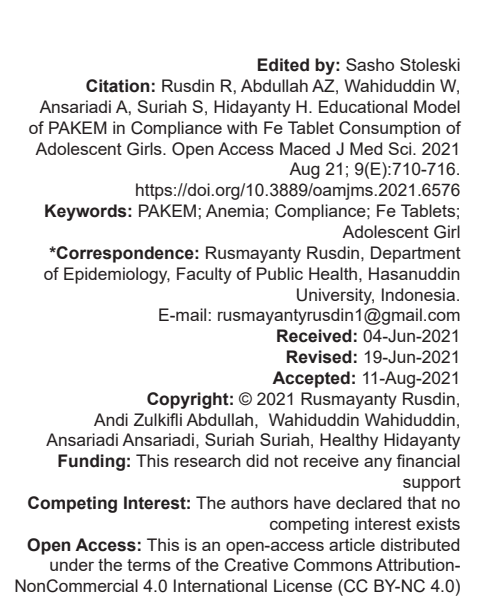

\begin{abstract}
BACKGROUND: The low adherence to consumption of Fe tablets in adolescent girls illustrates that the iron supplementation program has not been maximized, so the proportion of anemia in the adolescent group is still high. School-based weekly Fe tablet intervention together with education is effective and ideal in preventing anemia.

AIM: This study aims to determine the effect of the PAKEM education model on adherence to Fe tablet consumption.

METHODS: This research was quasi-experimental with the randomized pre-test-post-test control group design. The population of this study was 249 young women in Class XI of several high schools, SMAN 12 Makassar and SMAN 1 Makassar, based on the results of the initial survey with low adherence to taking Fe tablets. The research sample was obtained by simple random sampling; 70 respondents were divided into intervention and control groups. Data were analyzed using paired t-test, Wilcoxon test, and Mann-Whitney U-test.

RESULTS: There was an increase after the PAKEM educational intervention on knowledge (10.91-17.88), attitudes (56.11-73.60), motivation (38.05-53.49), and actions (0.83-7.34). There was a significant difference between the PAKEM intervention group and the leaflet and audiovisual controls on all study variables with $p=0.000(p<0.05)$.

CONCLUSION: The PAKEM education model was more influential than a leaflet and audiovisual media on the compliance of female adolescent Fe tablet consumption. It is recommended for health workers and educators to apply the PAKEM education model to prevent anemia in adolescent girls.
\end{abstract}

\section{Introduction}

Adolescence is a phase of life between childhood and adulthood characterized by physical and sexual maturity and the transition of social roles [1]. The rapid growth of adolescents makes adolescents in Indonesia bear three burdens of malnutrition, one of which is micronutrient deficiency [2]. Adolescent girls with anemia have more nutritional problems than those without anemia [3]. Iron deficiency anemia is one of the main causes of disability that has short-term and longterm impacts [4].

Anemia is when the hemoglobin concentration is lower than the normal limit in adolescent girls if the $\mathrm{Hb}$ level is $<12 \mathrm{~g} / \mathrm{dl}$ [5]. Anemia is a public health problem in a third of the world's population, with an increase of 114 million cases from 2000 to 2016, especially in developing countries with the highest prevalence in the 10-19 years age group and around $35 \%$ of the global disease burden stems from adolescence [6]. Based on Riskesdas, the proportion of anemia in the 15-24 years age group increased almost half from $18.4 \%$ in 2013 to $32 \%$ in 2018.
Iron is one of the crucial micronutrients that support the growth of adolescents, especially young women. However, not all can get iron from food. Iron supplementation is needed to meet the iron needs of adolescent girls and as iron reserves in the future [4]. School-based weekly iron interventions are effective and ideal in reducing $27 \%$ of anemia in women of childbearing age and as the primary intervention in preventing anemia [7]. Iron supplements are recommended but need to be supported with good adherence [8].

Of all young women in Indonesia who receive Fe tablets, only $1.4 \%$ of them are obedient to consuming 52 grains [9]. The coverage of giving $\mathrm{Fe}$ tablets to adolescent girls in Makassar City has increased since 2017 by $30.9 \%-66.8 \%$ in 2019 . However, based on an online survey conducted by UNICEF (2020) of more than 6000 young Indonesians, almost $90 \%$ of young women stopped taking Fe tablets during the COVID-19 pandemic.

Based on an initial survey conducted in several high schools, SMAN 12 Makassar and SMAN 1 Makassar, it was found that only $8.3 \%$ of students of SMAN 12 Makassar and $5.3 \%$ of students of SMAN 
1 Makassar had good compliance because most had never received an education about anemia and its prevention. Lack of knowledge, attitude, and motivation causes non-compliance with $\mathrm{Fe}$ tablet consumption. Interventions and strategies are needed to improve compliance. The use of various teaching strategies can increase student participation and learning, such as research conducted by Jalambo et al. (2018), where educational interventions in the form of lectures, discussions, posters, videos, booklets, and brochures have been shown to increase iron supplementation compliance among adolescent girls. When media and methods are combined, they will complement each other [10].

This study uses a health education program with the PAKEM approach to increase the knowledge, attitudes, motivation, and practice of taking Fe tablets for adolescent girls. PAKEM conditioned active learning situations, creative, effective, and fun. The application of PAKEM departs from the conventional learning model, which is considered less attractive and tends to be boring [11]. Hadi (2019), in his research, states that innovative learning models are very effective and significant in increasing student adherence to a subject [12]. Zakian's research (2019) also states that the role of educators in encouraging student activity through the PAKEM learning model shows an increase in students' obedience, awareness, and responsibility in religious activities [13]. The PAKEM education model is still very rarely used in health studies, this research needed to be executed to increase the adherence to taking Fe tablets for young women.

\section{Methods}

\section{The site and research design}

This research was conducted at Senior High Schools, SMAN 12 Makassar, and SMAN 1 Makassar. The type of research used was quasiexperimental with the randomized pretest-posttest control group design. The population of this research was Class XI students who have participated in the initial survey, about 249 adolescent girls who were divided into two schools, 128 samples in SMAN 12 Makassar and 121 samples in SMAN 1 Makassar with low adherence to taking Fe tablets. The selection of the intervention and control groups was made by lottery technique. It was obtained that SMAN 12 Makassar became the intervention group and SMAN 1 Makassar became the control group. The sampling technique was simple random sampling obtained from the calculation of the sample size formula as many as 70 respondents, each of which was 35 respondents in the intervention and control groups.

\section{Collecting data}

This study used primary and secondary data. Primary data were obtained from observations during research conducted online in both groups where the learning materials and eight Fe tablets had been previously sent through courier service. Collecting data were using online questionnaires with three measurements: Pre-test, post-test 1, and post-test 2 where the distance between pre-test and post-test 2 was 8 weeks. The questionnaires used were those that had been tested and declared valid and reliable, containing statements related to anemia (definition, signs and symptoms, causes, effects, and prevention of anemia) and $\mathrm{Fe}$ tablets (definition, benefits, recommendations for drinking, and side effects of drinking). Secondary data were obtained from the Health Office of South Sulawesi Province in coverage of giving Fe tablets to students aged 12-18 years in Makassar City and an overview of the research locations for the intervention and control groups.

\section{Data analysis}

Data analysis was performed by univariate and bivariate analysis. In bivariate analysis, data were analyzed using paired t-test, Wilcoxon test, and MannWhitney U-test. This research was approved by the Health Research Ethics Committee (KEPK) Faculty of Public Health, Hasanuddin University, Makassar, Indonesia (No:91120032307)10353/UN4.14.1/ TP.01.02/2020.

\section{Results}

The age of respondents in the intervention and control groups was mainly 16 years, with 31 respondents (88.6\%). Based on cross-tabulation results on adherence to $\mathrm{Fe}$ tablet consumption, 28 respondents $(90.3 \%)$ in the intervention group and 12 respondents $(38.7 \%)$ in the control group with good adherence were obtained. Most of the respondents with menarche age, in the age 12-13 years were 45 respondents $(64.3 \%), 26$ of them with good compliance, including 17 respondents $(89.5 \%)$ in the intervention group and 9 respondents (34.6\%) control group. Respondents based on majors from mathematics and natural sciences were 66 respondents (94.3\%), 42 respondents were obedient to taking Fe tablets, including 28 respondents $(90.3 \%)$ in the intervention group and 14 respondents (40\%) in the control group.

Respondents based on the father's last education mainly were high school/vocational school graduates, a total of 37 respondents $(52.9 \%)$ with an equivalent education level of STM/SMA, of which 26 
were included in the obedient category, namely, 18 respondents $(94.7 \%)$ in the intervention group and 8 respondents (44.4\%) control group. Meanwhile, based on the mother's latest education, it was known that as many as 47 respondents (67.1\%) with a high school/ vocational education level, of which 30 of them are obedient to taking Fe tablets, namely, 21 respondents $(91.3 \%)$ in the intervention group and 9 respondents (37, 5\%) control group. Based on the characteristics of the respondents, age and age of menarche, last education of mother and father, and majors, most of them with good adherence came from the intervention group (Table 1).

Characteristics of respondents based on the average score (mean) of knowledge, attitudes, and motivation increased from pre-test to post-test 1 in both the intervention and control groups. The mean score of knowledge increased from 10.91 to 17.00 and increased in post-test $2,17.88$, with a mean difference of $6.97(63.88 \%)$. The difference in the mean knowledge score between the intervention and control groups was $3.02(27.61 \%)$. Characteristics of respondents based on the mean attitude score at pre-test to post-test 1 in the intervention group from a mean score of $56.11-70.77$ and an increase also occurred in post-test 2, namely, 73.60 with a mean difference of 17.49 (31.17\%). The difference in the mean attitude score between the intervention and control groups was 7.69 (13.83\%).

The characteristics of respondents based on the mean score of motivation at pre-test to post-test 1 in the intervention group from the mean score of 38.05 increased to 50.00 and increased to post-test 2, namely, 53.48 with a mean difference of 15.43 (40.55\%). The control group was increased but decreased in posttest 2 . The difference in the mean score of motivation

Table 1: Distribution of respondent characteristics based on adherence with Fe tablet consumption in Makassar city

\begin{tabular}{|c|c|c|c|c|c|c|c|c|}
\hline \multirow[t]{4}{*}{ Respondent characteristics } & \multicolumn{8}{|c|}{ Group } \\
\hline & \multicolumn{4}{|c|}{ Intervention } & \multicolumn{4}{|c|}{ Control } \\
\hline & \multicolumn{2}{|c|}{ Adherence } & \multicolumn{2}{|c|}{ Not adhering } & \multicolumn{2}{|c|}{ Adherence } & \multicolumn{2}{|c|}{ Not adhering } \\
\hline & $\mathrm{n}$ & $\%$ & $\mathrm{n}$ & $\%$ & $\mathrm{n}$ & $\%$ & $\mathrm{n}$ & $\%$ \\
\hline \multicolumn{9}{|l|}{ Age } \\
\hline 16 years old & 28 & 90.3 & 3 & 9.7 & 12 & 38.7 & 19 & 61.3 \\
\hline 17 years old & 4 & 100 & 0 & 0 & 2 & 50 & 2 & 50 \\
\hline \multicolumn{9}{|l|}{ Majors } \\
\hline $\begin{array}{l}\text { Mathematics and natural } \\
\text { sciences }\end{array}$ & 28 & 90.3 & 3 & 9.7 & 14 & 40 & 21 & 60 \\
\hline Social sciences & 4 & 100 & 0 & 0 & 0 & 0 & 0 & 0 \\
\hline \multicolumn{9}{|l|}{ Father's education } \\
\hline $\begin{array}{l}\text { Not completed in elementary } \\
\text { school }\end{array}$ & 1 & 50 & 1 & 50 & 0 & 0 & 0 & 0 \\
\hline Elementary school & 1 & 100 & 0 & 0 & 1 & 100 & 0 & 0 \\
\hline Junior high school & 2 & 100 & 0 & 0 & 0 & 0 & 1 & 100 \\
\hline Senior high school & 18 & 94.7 & 1 & 5.3 & 8 & 44.4 & 10 & 55.6 \\
\hline Bachelor & 8 & 88.9 & 1 & 11.1 & 5 & 38.5 & 8 & 61.5 \\
\hline Master & 1 & 100 & 0 & 0 & 0 & 0 & 2 & 100 \\
\hline Doctoral & 1 & 100 & 0 & 0 & 0 & 0 & 0 & 0 \\
\hline \multicolumn{9}{|l|}{ Mother's education } \\
\hline Elementary school & 1 & 100 & 0 & 0 & 1 & 100 & 0 & 0 \\
\hline Junior high school & 2 & 100 & 0 & 0 & 1 & 100 & 0 & 0 \\
\hline Senior high school & 21 & 91.3 & 2 & 8.7 & 9 & 37.5 & 15 & 62.5 \\
\hline Bachelor & 7 & 87.5 & 1 & 12.5 & 2 & 25 & 6 & 75 \\
\hline Master & 1 & 100 & 0 & 0 & 1 & 100 & 0 & 0 \\
\hline \multicolumn{9}{|l|}{ Age of menarche } \\
\hline 10-11 years & 4 & 80 & 1 & 20 & 2 & 100 & 0 & 0 \\
\hline $12-13$ years & 17 & 89.5 & 2 & 10.5 & 9 & 34.6 & 17 & 65.4 \\
\hline $14-15$ years & 11 & 100 & 0 & 0 & 3 & 42.9 & 4 & 57.1 \\
\hline Total & 32 & 91.4 & 3 & 8.6 & 14 & 40 & 21 & 60 \\
\hline
\end{tabular}

between the intervention and control groups was $7.69(14.83 \%)$. Based on the action, it did not show an increase in the pre-test to post-test 1. However, it increased in post-test 2 in the intervention group in post-test 2 and the control group. The difference in the mean score between the intervention and control groups was 2.91 (285\%).

The statistical test of knowledge in both the intervention and control groups obtained $p=0.000$ $(p<0.05)$, meaning that there was an influence of the PAKEM education model and leaflet and audiovisual media on increasing respondents' knowledge about anemia and Fe tablets (Table 2). Statistical test results obtained the difference in knowledge scores of the two groups at the pre-test with $p=0.605$ ( $p>0.05)$, meaning that there was no difference in the mean score of initial knowledge between the intervention and control groups. The results of the statistical test at posttest 1 obtained $p=0.003(p<0.05)$ and at post-test 2 obtained $p=0.000(p<0.05)$, indicating that there was a difference in the mean score of knowledge between the intervention and control groups. The statistical test of attitudes in both the intervention and control groups obtained $p=0.000(p<0.05)$, meaning that there was an influence of the PAKEM education model and leaflet and audiovisual media on respondents' positive attitudes about anemia and $\mathrm{Fe}$ tablets. The difference in the attitude scores of the two groups with the results of the statistical test at the pre-test was obtained by $p=0.850(p$ $>0.05$ ), indicating that there was no difference in the mean initial attitude score between the intervention and control groups. The results of the statistical test at post-test 1 obtained $p=0.022(p<0.05)$ and at posttest 2 obtained $p=0.000(p<0.05)$, indicating that there was a difference in the mean attitude score between the intervention and control groups.

The statistical tests of motivation in both the intervention and control groups obtained $p=0.000$ ( $p<0.05)$, meaning that there was an effect of the PAKEM education model and leaflet and audiovisual media on respondents' motivation in consuming $\mathrm{Fe}$ tablets (Table 3 ). The difference in the motivation scores of the two groups with the results of the statistical test at the pre-test obtained $p=0.112$ ( $p$ $>0.05$ ) indicates that there was no difference in the mean initial motivation score between the intervention and control groups. The results of the statistical test at post-test 1 obtained $p=0.008(p<0.05)$ and at posttest 2 obtained $p=0.000(p<0.05)$ showed that there was a difference in the mean score of respondents' motivation between the intervention group and the control group. The results of statistical tests for both the intervention and control groups obtained $p=$ $0.000(p<0.05)$, meaning that the PAKEM education model and leaflet and audiovisual media influenced the respondents' actions in consuming $\mathrm{Fe}$ tablets. The difference in the score of the two groups with the statistical test results at pre-test and post-test 1 
Table 2: Characteristics of respondents based on knowledge, attitudes, motivations, and compliance actions scores of Fe tablet consumption in Makassar city

\begin{tabular}{|c|c|c|c|c|c|c|c|}
\hline \multirow[t]{2}{*}{ Statistical value } & \multicolumn{3}{|l|}{ Score } & \multirow[t]{2}{*}{ Different } & \multirow[t]{2}{*}{$\%$} & \multirow[t]{2}{*}{ Different mean (intervention-control) (\%) } & \multirow[t]{2}{*}{ p-value } \\
\hline & Pre-test & Post-test 1 & Post-test 2 & & & & \\
\hline \multicolumn{8}{|l|}{ Knowledge } \\
\hline \multicolumn{8}{|c|}{ Intervention group } \\
\hline Maximum & 13 & 19 & 20 & 7 & 53.85 & & \\
\hline Mean & 10.91 & 17.00 & 17.88 & 6.97 & 63.88 & & \\
\hline $\mathrm{SD}$ & 1.401 & 1.514 & 0.993 & & & & \\
\hline SE & 0.237 & 0.256 & 0.168 & & & & \\
\hline \multicolumn{8}{|l|}{ Control group } \\
\hline Maximum & 14 & 19 & 18 & 4 & 28.57 & & \\
\hline Mean & 10.89 & 15.71 & 14.71 & 3.82 & 35.08 & & \\
\hline SD & 1.997 & 1.964 & 2.037 & & & & \\
\hline SE & 0.337 & 0.332 & 0.344 & & & & \\
\hline \multicolumn{8}{|c|}{ Attitudes } \\
\hline \multicolumn{8}{|c|}{ Intervention group } \\
\hline Minimum & 42 & 62 & 65 & 23 & 54.76 & $7.69(13.83)$ & 0.000 \\
\hline Maximum & 68 & 80 & 80 & 12 & 17.65 & & \\
\hline Mean & 56.11 & 70.77 & 73.60 & 17.49 & 31.17 & & \\
\hline $\mathrm{SD}$ & 5.880 & 5.099 & 4.216 & & & & \\
\hline Minimum & 48 & 54 & 49 & 1 & 2.09 & & 0.000 \\
\hline Maximum & 69 & 79 & 79 & 10 & 14.45 & & \\
\hline Mean & 56.17 & 67.37 & 65.91 & 9.74 & 17.34 & & \\
\hline SD & 4.362 & 6.320 & 7.586 & & & & \\
\hline SE & 0.737 & 1.968 & 1.282 & & & & \\
\hline \multicolumn{8}{|c|}{ Motivations } \\
\hline \multicolumn{8}{|c|}{ Intervention group } \\
\hline Minimum & 29 & 41 & 45 & 16 & 55.17 & $7.69(14.83)$ & 0.000 \\
\hline Maximum & 46 & 60 & 60 & 14 & 30.43 & & \\
\hline Mean & 38.05 & 50.00 & 53.48 & 15.43 & 40.55 & & \\
\hline SD & 4.036 & 4.652 & 3.467 & & & & \\
\hline SE & 0.682 & 0.786 & 0.586 & & & & \\
\hline \multicolumn{8}{|l|}{ Control group } \\
\hline Minimum & 30 & 35 & 33 & 3 & 10 & & 0.000 \\
\hline Maximum & 43 & 59 & 59 & 16 & 37.21 & & \\
\hline Mean & 36.43 & 46.23 & 45.8 & 9.37 & 25.72 & & \\
\hline SD & 3.099 & 5.981 & 7.267 & & & & \\
\hline SE & 0.524 & 1.011 & 1.228 & & & & \\
\hline \multicolumn{8}{|c|}{ Actions } \\
\hline \multicolumn{8}{|c|}{ Intervention group } \\
\hline Minimum & 0 & 0 & 4 & 4 & $\infty$ & $2.91(285 \%)$ & 0.000 \\
\hline SD & 0.857 & 0.857 & 1.162 & & & & \\
\hline SE & 0.145 & 0.145 & 0.196 & & & & \\
\hline \multicolumn{8}{|l|}{ Control group } \\
\hline Minimum & 0 & 0 & 0 & 0 & 0 & & 0.000 \\
\hline Maximum & 5 & 5 & 8 & 3 & 60 & & \\
\hline Mean & 0.74 & 0.74 & 4.43 & 3.69 & 499 & & \\
\hline SD & 1.421 & 1.421 & 2.831 & & & & \\
\hline SE & 0.240 & 0.240 & 0.479 & & & & \\
\hline
\end{tabular}

Table 3: Differences in knowledge, attitude, motivation, and compliance actions on Fe tablet consumption in Makassar city

\begin{tabular}{clll}
\hline Mean value & Intervention group $(\mathrm{n}=35)$ & Control group $(\mathrm{n}=35)$ & $\mathrm{p}$-value \\
\hline Knowledge & & & \\
Pre-test & 10.91 & 10.91 & 0.605 \\
Post-test 1 & 17 & 17 & 0.003 \\
Post-test 2 & 17.88 & 17.88 & 0.000 \\
Attitude & & & \\
Pre-test & 56.11 & 56.17 & 0.850 \\
Post-test 1 & 70.77 & 67.37 & 0.022 \\
Post-test 2 & 73.60 & 65.91 & 0.000 \\
Motivation & & & \\
Pre-test & 56.17 & 36.43 & 0.077 \\
Post-test 1 & 67.37 & 46.23 & 0.077 \\
Post-test 2 & 65.91 & 45.8 & 0.000 \\
Actions & & & \\
Pre-test & 36.43 & 0.74 & 0.74 \\
Post-test 1 & 46.23 & 0.74 & 0.74 \\
Post-test 2 & 45.8 & 4.43 & 4.43 \\
\hline
\end{tabular}

obtained $p=0.077(p>0.05)$, indicating no difference in the mean score of the respondents taking $\mathrm{Fe}$ tablets adherence between the intervention and control groups. The statistical test results at post-test 2 obtained $p=0.000(p<0.05)$, indicating a difference in the mean score of the respondents taking Fe tablets between the intervention and control groups.

\section{Discussion}

This study shows differences in the increase in compliance of $\mathrm{Fe}$ consumption before and after the PAKEM intervention. The increase in compliance occurred due to the mean score at pre-test to posttest 1 and post-test 1 to post-test 2 on respondents' knowledge, attitudes, and motivation. The increase in the pre-test to post-test 1 was because the respondent had never received education related to anemia and its prevention which caused the score to increase after being given the intervention. The increase in post-test 1 to post-test 2 was due to weekly control using leaflets, videos, modules, and posters as reading material so that memory deposition occurred to maintain knowledge until post-test 2 .

This study also showed differences in the increase in compliance of respondents' $\mathrm{Fe}$ tablet consumption before and after leaflet and audiovisual control. The increase in compliance occurred because 
respondents' knowledge, attitudes, and motivation increased from pre-test to post-test 1, although there was a decrease in mean scores from post-test 1 to posttest 2 due to the absence of weekly control. However, intervention and control groups' action was no increase in the pre-test to post-test 1 since the measurements were taken immediately after the intervention, while the post-test 1 to post-test 2 increased due to weekly reminders by the researcher before taking Fe tablets.

PAKEM originates from the concept that learning is participant centered and interesting to be motivated to explore and be creative by combining several methods and media to be participatory, active, creative, effective, and fun [11]. The PAKEM method used in this study were lectures, group discussions, problem-solving, and game simulations (quiz, role-play, and matching cards) with the help of posters, leaflets, videos, and game applications. The participatory component is indicated by the direct involvement of respondents in receiving the material using the lecture method as an introduction to getting to know anemia briefly so that respondents obtain basic information on the material provided.

The active component is demonstrated through group discussions. When giving an intervention, an atmosphere is created that triggers respondents to be active in asking questions and interested in expressing opinions, analyzing, and mastering the material provided to gain new understanding and draw conclusions that can then be applied in everyday life. The active process in learning aims to understand what has been taught where respondents' involvement is more than just listening; but need to understand, analyze, and be creative to solve problems [14]. Active learning activities can also result in more effective learning [15].

Based on the statistical test of knowledge of the two groups, there was a difference in the mean value of the intervention group, with a difference of $27.61 \%$ higher than the control group. This study is in line with Pratiwi et al. (2019) which showed that PAKEM intervention could increase student learning activities by increasing knowledge from cycle I by $62 \%$ to $86 \%$ in cycle II [16]. Another study conducted by Jalambo et al. (2017) showed that there was an effect of nutrition education programs using various methods, namely, lectures, presentations, discussions, interactive, posters, booklets, and nutrition brochures resulting in positive changes in the knowledge of respondents after the intervention of $22.7 \%-90.9 \%$ [10]. Hence, it can be concluded that the PAKEM education model is more influential than a leaflet and audiovisual media on increasing knowledge about anemia and $\mathrm{Fe}$ tablets. School-based health education plays a key role in increasing students' knowledge. Respondents often ask researchers about anemia and Fe tablets to assume that taking Fe tablets are fun and healthy. By increasing the knowledge of respondents, it can affect attitudes and also motivation in consuming Fe tablets.
Based on the attitude variable statistical test results, the two groups were equally significant, but there was a difference in the mean value of the intervention group, which was $13.83 \%$ higher than the control group. This study is in line with Jalambo et al.'s (2017) research, which showed an effect of nutrition education programs on attitude scores from $36.4 \%$ to $75.5 \%$ of respondents with good attitudes after the intervention [10]. Hence, it can be concluded that the PAKEM education model is more influential than a leaflet and audiovisual media on increasing attitudes about anemia and Fe tablets.

Based on the statistical test of motivational variables, the two groups were equally significant, but there was a difference in the mean value of the intervention group, which was $14.83 \%$ higher than the control group. Respondents view that anemia must be prevented, where the knowledge and positive attitude that has been formed will be a strong motivation to be applied into an action. This research is in line with that conducted by Bahtiar (2019) that the application of behavior system-based PAKEM learning has succeeded in increasing students' learning motivation with indicators of thinking skills. Hence, it can be concluded that the PAKEM education model is more influential than a leaflet and audiovisual media on increasing motivation to consume Fe tablets [17].

Both groups had differences before and after the PAKEM education intervention and leaflet and audiovisual media controls in this study. The respondent's adherence to taking Fe tablets weekly for 8 weeks was higher in the PAKEM intervention group by $91.4 \%$ than the control group by $40 \%$. Different results were found after the PAKEM education intervention, some respondents in both the intervention and control groups were due to the lack of motivation of respondents to make changes. Hence, it can be concluded that the PAKEM education model is more influential than a leaflet and audiovisual media on increasing adherence to Fe tablet consumption.

The creative aspect is shown through problemsolving related to the problem of anemia experienced by young women. The material presented creatively can stimulate thinking creatively by finding previously unknown information or taking action [11]. Respondents suggested alternative solutions to anemia, which are especially common among young women, namely, about what needs to be known and what needs to be done to prevent anemia, one of which is taking $\mathrm{Fe}$ tablets.

PAKEM creates intimacy between the researcher and the respondents so that they do not hesitate in exchanging ideas. Based on the results of statistical tests, the two groups were equally significant, but there was a difference in the mean value of the intervention group's compliance action of 2.91 (285\%), which was higher than the control group. Mentoring and supervision of taking Fe tablets were carried out in both groups, reinforced by evidence of taking Fe tablets in 
the form of photos or videos. Self-reporting surveys are the most convenient way of measuring respondent strategies [18]. Knowing the purpose and benefits of $\mathrm{Fe}$ tablets, most respondents showed an increase in taking frequency.

Another thing that affects the increase in adherence in the intervention group is creating a simple educational video related to anemia in adolescent girls. It includes the creative aspect. Participants are said to be creative if they can do something that produces new activities obtained from the results of creative thinking by making it happen in the form of a new job [11]. Researchers made educational videos and then distributed them to respondents' social media accounts and this became a challenge for them to understand anemia and the role of $\mathrm{Fe}$ tablets and be able to stimulate respondents' ability to think and remember the material that had been given through educational videos.

Suryani's research (2020) states that there is an effect of health promotion on the consumption of $\mathrm{Fe}$ tablets in young women after being given education using the lecture method with a mean of 7.95 and group discussion with a mean of 9.15 [19]. Another similar study also conducted by Jalambo et al. (2017) showed a correlation to the increase in consuming weekly $\mathrm{Fe}$ tablets for young women after being given nutrition education to prevent anemia from $54.5 \%$ to $75.5 \%$ [10]. This is reinforced by Abu-Baker et al. (2021) who used nutrition education interventions to effectively increase iron knowledge, attitudes, and practices in adolescent girls with iron deficiency anemia [20].

The effective aspect is through the provision of modules and audiovisual materials related to anemia. Effective learning needs to be supported by a conducive atmosphere and environment so that the presenters must manage the participants, the activities carried out, the content/materials provided, and the educational media used [11]. We also provide interesting education through game simulations in matching cards, quizzes, and role-playing. It is a new thing for respondents, so it does not cause a sense of saturation in understanding the information provided. Role-playing is very effective in triggering active learning, where students learn how to deal with real situations and problems and increase self-confidence and motivation to learn [21]. Pisano et al. (2020) also mentioned that game-based learning creates a fun atmosphere in honing the critical thinking skills of resident doctors in examining anemic patients because it can improve clinical reasoning and medical practice abilities [22].

Besides giving the method, the atmosphere and process of providing materials are also the main factors in the intervention's success. A conducive atmosphere and complete facilities also attractively packaged materials made respondents feel comfortable and enthusiastic in receiving the material. Those may improve knowledge, attitudes, and motivation. The
PAKEM education model can be used for research to provide education, but possibly to use in health education with a variety of different materials and targets. This education model increase understanding and change one's perceptions, attitudes, motivations, and behavior. According to Pratiwi et al. (2019), PAKEM is a learning-by-work approach to carry out various activities in developing their skills, attitudes, and understanding [16].

\section{Conclusion}

The results showed differences before and after the PAKEM educational intervention on the mean scores of knowledge, attitudes, motivation, and compliance actions of respondents' $\mathrm{Fe}$ tablet consumption. The increase in adherence was more dominantly shown in the group given PAKEM education than the control group through leaflets and audiovisual media. It can be concluded that the PAKEM education model is more influential than a leaflet and audiovisual media on female students' $\mathrm{Fe}$ tablet consumption compliance. It is recommended for health workers and educators to apply the PAKEM education model to prevent anemia in adolescent girls.

\section{References}

1. Sawyer SM, Azzopardi PS, Wickremarathne D, Patton GC The age of adolescence. Lancet Child Adolesc Health. 2018;2(3):223-8. https://doi.org/10.1016/s2352-4642(18)30022-1 PMid:30169257

2. UNICEF Indonesia. Upaya Remaja Mencegah Anemia; 2020 Available from: https://www.unicef.org/indonesia/id/coronavirus/ cerita/upaya-remaja-mencegah-anemia. [Last accessed on 2021 Jun 04]. https://doi.org/10.31219/osf.io/e5y7s

3. Oy S, Witjaksono F, MustafaA, Setyobudi SI, Fahmida U. Problem nutrients in adolescent girls with anemia versus nonanemic adolescent girls and the optimized food-based recommendations to meet adequacy of these nutrients in adolescent school girls in East Java, Indonesia. Food Nutr Bull. 2019;40(3):295-307. https://doi.org/10.1177/0379572119851326

PMid:31272219

4. Kemenkes RI. Profil Kesehatan Indonesia 2018 Jakarta: Kementerian Kesehatan RI; 2019. https://doi. org/10.32922/jkp.v8i2

5. World Health Organization. Anaemia. Geneva: World Health Organization; 2020. Available from: https://www.who.int/ westernpacific/health-topics/anaemia. [Last accessed on 2021 Jun 04]

6. World Health Organization. Global Health Observatory Data Repository. Geneva: World Health Organization; 2019. Available from: https://apps.who.int/gho/data/view.main. anaemiawomen\%20npwreg. [Last accessed on 2021 Jun 04]. 
7. Roche ML, Bury L, Yusadiredja IN, Asri EK, Purwanti TS, Kusyuniati $\mathrm{S}$, et al. Adolescent girls' nutrition and prevention of anaemia: A school based multisectoral collaboration in Indonesia. BMJ. 2018;363:k4541. https://doi.org/10.1136/bmj.k4541 PMid: 30530813

8. Compaoré A, Gies S, Brabin B, Tinto H, Brabin L. Community approval required for periconceptional adolescent adherence to weekly iron and/or folic acid supplementation: A qualitative study in rural Burkina Faso. Reprod Health. 2018;15(1):48. https://doi.org/10.1186/s12978-018-0490-y PMid:29540225

9. Kemenkes RI. Main Results of Riskesdas 2018. Kementerian Kesehatan RI; 2018.

10. Jalambo M, Karim N, Naser I, Sharif R. Effects of iron supplementation and nutrition education on haemoglobin, ferritin and oxidative stress in iron-deficient female adolescents in Palestine: Randomized control trial. East Mediterr Health J. 2018;24(6):560-8. https://doi.org/10.26719/2018.24.6.560 PMid:30079951

11. Rusman. Model-model Pembelajaran (Mengembangkan Profesionalisme Guru). Jakarta: Raja Grafindo Persada; 2014.

12. Hadi. Inovasi Model Pengajaran Berbasis Karakter dalam Meningkatkan Ketaatan dan Kepatuhan Pada Mata Pelajaran Akidah Akhlak Siswa MTs NU Demak Tahun Pelajaran 2017/2018. [Kudus]: Program Studi Manajemen Pendidikan Islam (MPI) Pascasarjana IAIN Kudus; 2019. https://doi. org/10.21043/quality.v5i2.3063

13. Zakian M. Peran Guru Dalam Mendorong Keaktifan Siswa Mengikuti Kegiatan Keagamaan Di SMP Islam Sudirman Kecamatan Tengaran Tahun Pelajaran 2018/2019. [Salatiha]: Institut Agama Islam Negeri Salatiga, Fakultas Tarbiyah dan IImu Keguruan Jurusan Pendidikan Agama Islam; 2019. https:// doi.org/10.30596/intiqad.v10i2.1949

14. Morgan S, Martin L, Howard B, Mihalek PH. Active learning: What is it and why should I use it? Dev Bus Simul Exp Learn. 2005;32:219-23.

15. Stains M, Harshman J, Barker MK, Chasteen SV, Cole R,
DeChenne-Peters SE, et al. Anatomy of STEM teaching in american universities: A snapshot from a large-scale observation study. Science. 2018;359(6383):1468-70.

PMid:29599232

16. Pratiwi NF, Djumhana N, Hermawan R. The application of the PAKEM approach to improve the learning activities of third grade elementary school students. J Pendidikan Guru Sekolah Dasar. 2019;4(2):26-37. https://doi.org/10.33578/jpfkip.v7i1.5350

17. Bahtiar RS. PAKEM berbasis sistem perilaku dalam peningkatan motivasi belajar siswa sekolah dasar. J Inov Pend Dasar. 2020;4(1):1-5. https://doi.org/10.36928/jipd.v4i1.312

18. Panadero $\mathrm{E}$, Klug J, Järvelä $\mathrm{S}$. Third wave of measurement in the self-regulated learning field: When measurement and intervention come hand in hand. Scand J Educ Res. 2016;60(6):723-35. https://doi.org/10.1080/00313831.2015.106 6436

19. Suryani L. The Effectiveness of Lecture Methods and Group Discussions on Adolescent Compliance Consuming BloodAdding Tablets. J Midwifery Sci. 2020;4(1):46-54. https://doi. org/10.36341/jomis.v4i1.1110

20. Abu-Baker NN, Eyadat AM, Khamaiseh AM. The impact of nutrition education on knowledge, attitude, and practice regarding iron deficiency anemia among female adolescent students in Jordan. Heliyon. 2021;7(2):e06348. https://doi. org/10.1016/j.heliyon.2021.e06348

PMid:33718648

21. Dorri S, Farahani MA, Maserat E, Haghani H. Effect of roleplaying on learning outcome of nursing students based on the Kirkpatrick evaluation model. J Educ Health Promot. 2019;8(1):197.

PMid:31867374

22. John PT, Valeria S, Marcelo H, Dipal P, Georgina O. The bloody board game: A game-based approach for learning high-value care principles in the setting of anemia diagnosis. MedEdPORTAL. 20202;16:11057. https://doi.org/10.15766/ mep_2374-8265.11057

PMid:33365391 